Contract No. and Disclaimer:

This manuscript has been authored by Savannah River Nuclear Solutions, LLC under Contract No. DE-AC09-08SR22470 with the U.S. Department of Energy. The United States Government retains and the publisher, by accepting this article for publication, acknowledges that the United States Government retains a non-exclusive, paid-up, irrevocable, worldwide license to publish or reproduce the published form of this work, or allow others to do so, for United States Government purposes. 


\title{
Environmental Reactivity of Solid State Hydride Materials: Modeling and Testing for Air and Water Exposure
}

\author{
D.L. Anton ${ }^{\text {a }}$, C.W. James, D.A. Tamburello, \\ J.A. Cortes, J.R. Gray, and K.S. Brinkman \\ Savannah River National Laboratory, Aiken, SC, 29808, USA \\ a donald.anton@srnl.doe.gov
}

\begin{abstract}
$\underline{\text { Abstract }}$
To make commercially acceptable condensed phase hydrogen storage systems, it is important to understand quantitatively the risks involved in using these materials. A rigorous set of environmental reactivity tests have been developed based on modified testing procedures codified by the United Nations for the transportation of dangerous goods. Potential hydrogen storage material, $2 \mathrm{LiBH}_{4} \cdot \mathrm{MgH}_{2}$ and $\mathrm{NH}_{3} \mathrm{BH}_{3}$, have been tested using these modified procedures to evaluate the relative risks of these materials coming in contact with the environment in hypothetical accident scenarios. It is apparent that an ignition event will only occur if both a flammable concentration of hydrogen and sufficient thermal energy were available to ignite the hydrogen gas mixture. In order to predict hydride behavior for hypothesized accident scenarios, an idealized finite element model was developed for dispersed hydride from a breached system. Empirical thermodynamic calculations based on precise calorimetric experiments were performed in order to quantify the energy and hydrogen release rates and to quantify the reaction products resulting from water and air exposure. Both thermal and compositional predictions were made with identification of potential ignition event scenarios.
\end{abstract}

Keywords: Hydrogen storage, Metal Hydride, Environmental Reactivity, Water Exposure, Air Exposure 


\section{Introduction}

Although extensive studies exist on the safety properties of hydrogen gas itself [1-3] less is known about the reactivity of solid state hydrogen storage materials when exposed to the environmental surroundings (i.e.- water, water vapor, and air). It is important to understand the risks in using these materials such as in the case of a hydrogen storage tank being breached and hydride material that is exposed to the environment or dispersed onto the ground. The assessment of risks associated from hydrogen gas release and ignition; along with the flammability of resultant dehydrogenation products are critical. A number of early reports focusing on $\mathrm{NaAlH}_{4}$ were made in preparation for handling and building prototype hydrogen storage systems [4a-4c]. This report generated and compiled data including the identification of gas and solid products resulting from air and water exposure. More recently, other publications have been published that discusses safety aspects of such materials as $\mathrm{NaAlH}_{4}$ and $8 \mathrm{LiH} \cdot 3 \mathrm{Mg}\left(\mathrm{NH}_{2}\right)_{2}[4,5]$.

This report will discuss the environmental reactivity of two potential hydrogen storage materials: a destablized mixture of lithium borohydride $\left(\mathrm{LiBH}_{4}\right)$ and magnesium hydride $\left(\mathrm{MgH}_{2}\right)$ in a molar ratio of 2 to 1, respectively and the chemical hydride amonia

borane. For the destabilized $\mathrm{LiBH}_{4}$ material, Vajo et al[6] showed that the formation of $\mathrm{MgB}_{2}$ during dehydrogenation stablizes the $\mathrm{LiBH}_{4}$ and reduces the enthalpy of reaction. The "destabilized" mixture has been reported to have a >10wt\% $\mathrm{H}_{2}$ capacity and rechargeable under reasonable pressure and temperature ( 1 to $10 \mathrm{~atm}$ and 20 to $\left.100^{\circ} \mathrm{C}\right)[6,7]$.

$$
\mathrm{LiBH}_{4}+\frac{1}{2} \mathrm{MgH}_{2} \leftrightarrow \mathrm{LiH}+\frac{1}{2} \mathrm{MgB}_{2}+2 \mathrm{H}_{2}
$$

The second material of interest, ammonia borane $\left(\mathrm{NH}_{3} \mathrm{BH}_{3}\right)$, has been the subject of a number of studies as a chemical hydride due to its high hydrogen capacity (19 wt\%) and low dehydrogenation temperature of $100^{\circ} \mathrm{C}(373 \mathrm{~K})$ [9,10]. Furthermore, ammonia borane has good thermal stability and is readily available commercially.

The purpose of this paper is to explain the details related to an idealized computational model that was developed to explain the hazards associated with these materials being dispersed from a hydrogen storage tank for a breach-of-tank scenario. The model takes into account empirical thermodynamic data obtained using isothermal calorimetry, where each material can be exposed to various degrees of liquid water, water vapor, and air contact. Calorimetry allows for time resolved data such as heat and hydrogen generation and rate of reaction to be measured for various environmental exposure scenarios. These results are then input into the finite element model, to gain insight to the spatially resolved reaction rates with both thermal and compositional information. It will be shown that time and location for coincidental hydrogen minimum ignition temperature and minimum flammability concentration can be resolved. Such studies give insight into environmental exposure scenarios and, ultimately, will help reduce the number of experiments needed to explain the environmental reactivity behavior of different solid-state hydrogen storage materials.

\section{Experimental Procedures}

Specimens were prepared by mixing commercially pure $\mathrm{MgH}_{2}$ and $\mathrm{LiBH}_{4}$. Milling was conducted in a Spex mill for $1 \mathrm{hr}$., under an argon atmosphere with a ball-to-sample ratio of 20 to 3. Ammonia Borane was purchased commercially from Sigma Aldrich and used asreceived. Approximately 3 grams of ammonia borane was discharged using a Sievert's apparatus at $180^{\circ} \mathrm{C}$ (heating rate of $10^{\circ} \mathrm{C} / \mathrm{min}$ ) and 1 bar of backpressure for 3 hours. 
To quantify the heat released through contact with dry and humidified air and liquid water, oxidation and hydrolysis studies were performed in a Calvet calorimeter. Liquid water tests were performed using a mixing cell with $\mathrm{pH}$-neutral water to react 5-10 $\mathrm{mg}$ of solid with $1 \mathrm{ml}$ of water. Controlled humidity air reaction measurements were conducted at varying relative humidity levels $(0-80 \% \mathrm{RH})$ and temperatures $\left(40\right.$ and $\left.70{ }^{\circ} \mathrm{C}\right)$. For these measurements, the calorimeter equipped with a flow cell utlilizing either argon or air as the carrier gas with a flow rate of $10 \mathrm{ml} / \mathrm{min}$ reacting with $5-10 \mathrm{mg}$ of solid. [8, 9]. Thermal Gravimetric Analysis (TGA) was utilized at various heating heats $\left(0.8,2,5\right.$, and $\left.10{ }^{\circ} \mathrm{C} / \mathrm{min}\right)$ to determine the kinetics of ammonia borane, which was inputted into the modeling effort. In addition, residual gas analysis (RGA) was used to quantify the amount of impurities with respect to hydrogen for the gas released during testing.

\section{Modeling}

The governing equations solved for each analysis include mass, momentum, and energy balances, plus additional kinetics equations based on the chemical kinetics data. The following assumptions were made to simplify the analysis:

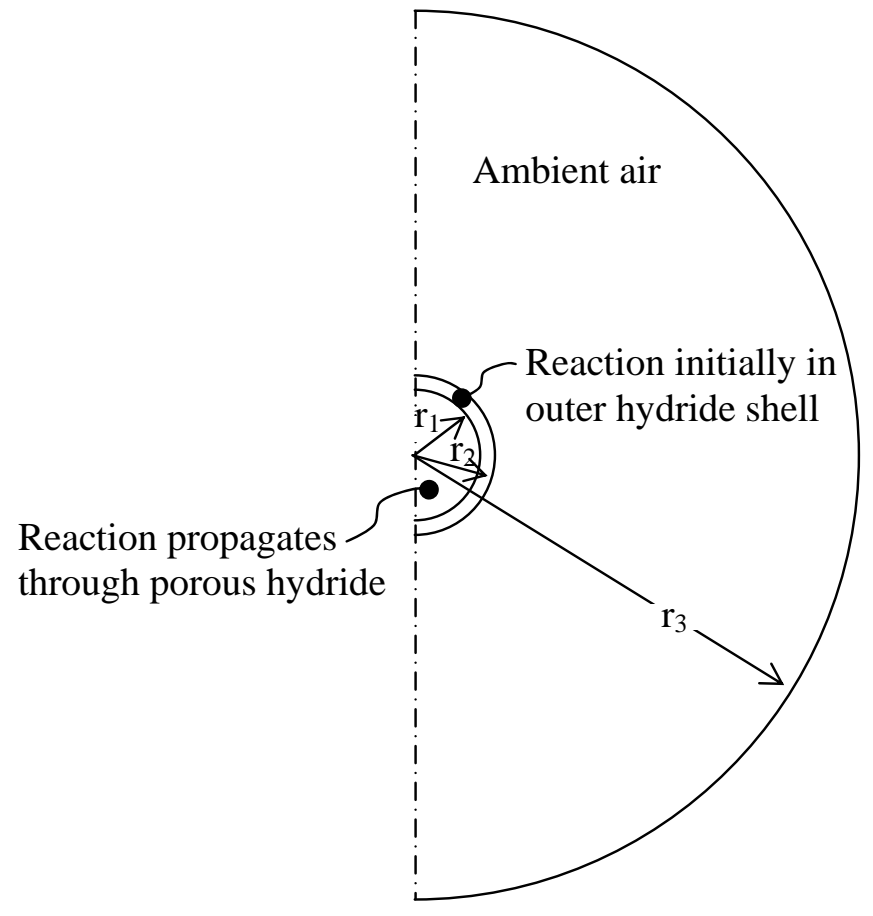

Figure 1: Schematic of sphere used in modeling of $2 \mathrm{LiBH}_{4} \cdot \mathrm{MgH}_{2}$.

- The ambient fluid is dry air.

- The calorimetry data at $70{ }^{\circ} \mathrm{C}$ for the liquid water and $2 \mathrm{LiBH}_{4}: \mathrm{MgH}_{2}$ is assumed to be the worst case scenario with the fast reaction rate and highest heat of reaction for this system.

- The heat and mass generation source is based upon the worst case scenario as stated in the assumption above and is modeled as temperature, pressure, and material composition independent. Thus, the heat and mass generation source, which varies with time and position, will continue regardless of the fluid or material temperature, fluid pressure, or species concentrations.

- All reactions begin in the outer shell of the hydride sphere. 
- The material is a uniform $50 \%$ porous sphere.

- Mass transport considerations and limitations within the porous sphere that would be present due to binders or other pelletization considerations are not addressed in this work.

- The material properties are constant during the simulation.

- The ambient air properties are allowed to change with temperature and pressure via the ideal gas law.

The built-in hydrogen-air reaction within FLUENT [9] is used to mark the hydrogen ignition even when/if it occurs. However, the model is only designed to capture the events leading up to the ignition event and is not designed to model the ignition event itself or the events following the ignition event

\section{Results and Discussion}

\section{UN Derivative Testing}

Six tests were adopted from United Nation's protocol on the Transport of Dangerous Goods [10] to evaluate the flammability and water reactivity of various solid state hydrogen storage materials. Table 1 is a summary of these test results. When describing the material's environmental reactivity, the tests are divided into two categories: Flammability and Water Contact. Flammability tests include pyrophoricity, self-heating, and burn rate. Water reactivity focuses on material contact with water, which includes water immersion, surface exposure (contact), and water drop. The $2 \mathrm{LiBH}_{4} \cdot \mathrm{MgH}_{2}$ is less reactive by an order of magnitude, than data reported for $8 \mathrm{LiH} \cdot \mathrm{Mg}\left(\mathrm{NH}_{2}\right)_{2}$ and $\mathrm{NaAlH}_{4}[4,5]$ in both flammability (burn rate) and water reactivity. Ammonia borane is the least reactive hydrogen storage material with respect to $2 \mathrm{LiBH}_{4} \cdot \mathrm{MgH}_{2}, 8 \mathrm{LiH} \cdot \mathrm{Mg}\left(\mathrm{NH}_{2}\right)_{2}$, and $\mathrm{NaAlH}_{4}$ based on the behavior observed during the environmental exposure involved in the series of UN tests. The only test ammonia borane failed was that of self-heating. The material self-heated to close to $300^{\circ} \mathrm{C}$, possibly due to the oven temperature being close to the dehydrogenation temperature of ammonia borane and a large flux of hydrogen available. No water reaction was observed.

Table 1: UN Testing results for $2 \mathrm{LiBH}_{4} \cdot \mathrm{MgH}_{2}$ and $\mathrm{NH}_{3} \mathrm{BH}_{3}$.

\begin{tabular}{|c|c|c|c|c|c|c|c|}
\hline Material / UN Test & State & Pyrophoricity & Self-Heat & Burn Rate & Water Drop & $\begin{array}{l}\text { Surface } \\
\text { Contact }\end{array}$ & $\begin{array}{c}\text { Water } \\
\text { Immersion }\end{array}$ \\
\hline $\begin{array}{c}2 \mathrm{LiBH}_{4} \cdot \mathrm{MgH}_{2} \\
\text { SRNL }\end{array}$ & $\mathrm{C}$ & $\begin{array}{l}\text { No ignition } \\
\text { event. } \\
\text { Hygroscopic } \\
\text { material } \\
\text { absorbed } \mathrm{H}_{2} \mathrm{O} \\
\text { from air. }\end{array}$ & $\begin{array}{l}\text { Self-heated } \\
\sim 300^{\circ} \mathrm{C} \\
\text { within } 5 \mathrm{~min} \\
\text { as } \mathrm{T}_{\text {oven }}= \\
150^{\circ} \mathrm{C} \text { is } \\
\text { approached. }\end{array}$ & $\begin{array}{l}\text { Flame } \\
\text { propagated in } \\
5 \mathrm{sec} \text { with } \\
\text { burn rate of } \\
52 \mathrm{~mm} / \mathrm{sec} \text {. }\end{array}$ & $\begin{array}{l}2 \mathrm{H}_{2} \mathrm{O} \text { drops } \\
\text { required for near- } \\
\text { instant ignition. }\end{array}$ & Material ignited & $\begin{array}{l}\text { No ignition } \\
\text { event recorded. } \\
\text { Gas evolved at } \\
\text { longer times. } \\
(5 \text { min) }\end{array}$ \\
\hline $\begin{array}{c}\mathbf{N H}_{3} \mathbf{B H}_{3} \\
\text { SRNL }\end{array}$ & $\mathrm{C}$ & $\begin{array}{l}\text { No ignition } \\
\text { event. } \\
\text { Hygroscopic } \\
\text { material } \\
\text { absorbed } \mathrm{H}_{2} \mathrm{O} \\
\text { from air. }\end{array}$ & $\begin{array}{l}\text { Self-heated } \\
\sim 300{ }^{\circ} \mathrm{C} \\
\text { within } 10 \\
\text { min, } 5 \text { min at } \\
\mathrm{T}_{\text {over }}=150^{\circ} \mathrm{C}\end{array}$ & $\begin{array}{l}\text { Flame } \\
\text { propagated in } \\
6 \text { sec with } \\
\text { burn rate of } \\
33 \mathrm{~mm} / \mathrm{sec}\end{array}$ & $\begin{array}{l}\text { No reactivity } \\
\text { detected }\end{array}$ & $\begin{array}{l}\text { No ignition } \\
\text { event recorded. } \\
\text { Gas evolved at } \\
\text { longer times. } \\
\text { (5 min) }\end{array}$ & $\begin{array}{l}\text { No reactivity } \\
\text { detected }\end{array}$ \\
\hline
\end{tabular}




\section{$2 \mathrm{LiBH}_{4} \cdot \mathrm{MgH}_{2}$}

\section{Calorimetry}

Figure 2 displays the normalized heat flow (mW/mg) for the $2 \mathrm{LiBH}_{4}: \mathrm{MgH}_{2}$ reaction with liquid water in a mixing cell compared with water vapor in a gas flow cell[ 8,11$]$. The amount of total water addition in excess of stoichiometry is 32 times for liquid water and 4 times (after a reaction time of 12 hours) for the conditions of $40^{\circ} \mathrm{C}$ and $30 \%$ relative humidity. The qualitative difference observed for heat flow is believed to be due to the difference in gas/solid versus liquid/solid interfacial reactions and is currently under further investigation. The total energy release of the water vapor reaction was greater $(-268 \mathrm{~kJ} / \mathrm{mol})$ than the energy release upon liquid water hydrolysis $(-223 \mathrm{~kJ} / \mathrm{mol})$. In addition the final crystalline reaction products were different in the two cases: the reaction with $30 \%$ relative humidity air resulted in $\mathrm{LiB}(\mathrm{OH})_{4}$ and residual $\mathrm{MgH}_{2}$, while the liquid water hydrolysis resulted in $\mathrm{LiB}(\mathrm{OH})_{4}, \mathrm{H}_{6} \mathrm{~B}_{2} \mathrm{O}_{6}$ and $\mathrm{LiB}(\mathrm{OH})_{2}\left(\mathrm{O}_{2}\right)$ phases along with amorphous components. Overall, in both the liquid mixing and gas flow reactions the trend is for a lower measured energy compared to the thermodynamically predicted reactions. As reported earlier, these discrepancies are to the fact that the actually observed products do not match those predicted from thermodynamics and often have a significant degree of amorphous character. Despite discrepancies in theoretical versus experimental heat release, the kinetics of energy release empirically determined for these materials via calorimetry will be used as inpt data for modeling the environmental reactivity under accident scenarios as described in the subsequent section.

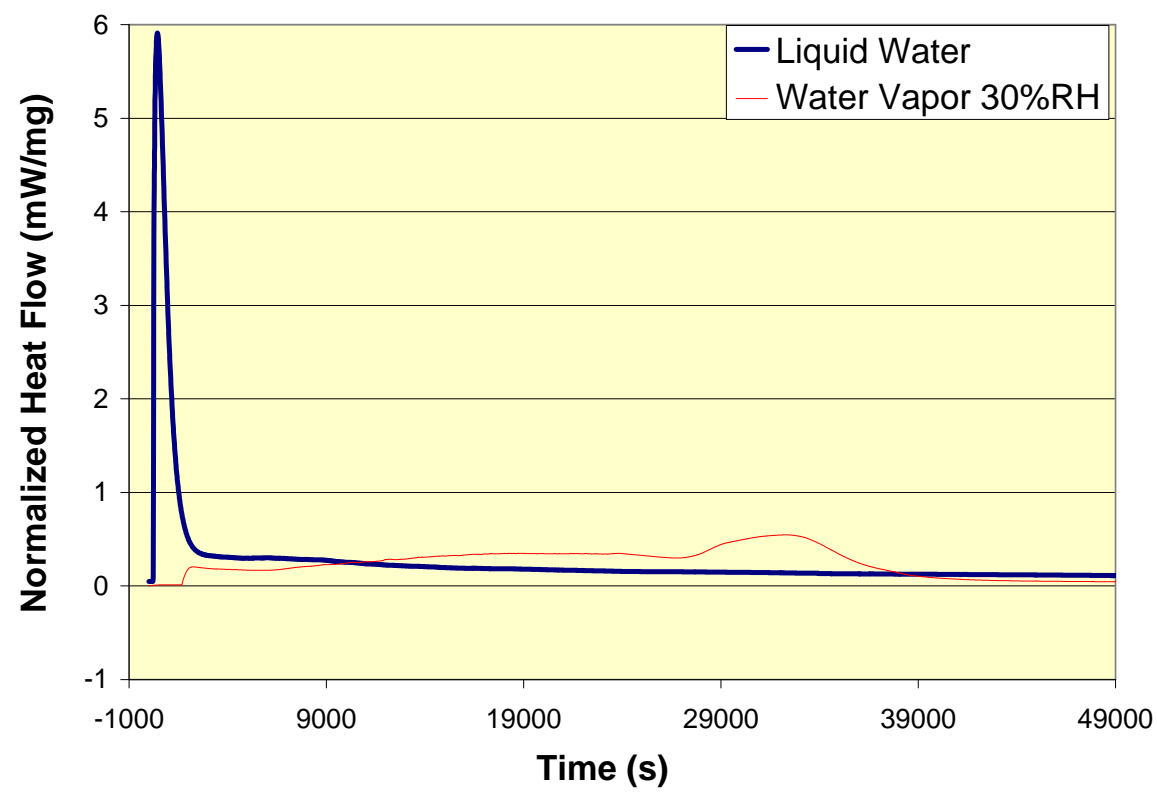

Figure 2: Normalized heat flow (mW/mg) during hydrolysis/oxidation of $2 \mathrm{LiBH}_{4} \cdot \mathrm{MgH}_{2}$ with liquid water at $40^{\circ} \mathrm{C}$ and with $30 \%$ relative humidity air at $40^{\circ} \mathrm{C}(10 \mathrm{ml} / \mathrm{min}$ flow rate).

\section{Modeling}

The first risk mitigation strategy for a self heating powder would be to pelletize it so that fine particles do not react with air and or ambient water vapor. In this instance it is important to identify what maximum diameter pellet would self heat to the point where the minimum hydrogen ignition temperature was reached. Two different "accident" scenarios were considered for material in a spherical pelletized form of varying radii: (i) air has completely 
penetrated the intergranular space within the pellets and (ii) hydrogen still occupies the intergranular space.

For the first scenario, the hydride is initialized with ambient air filling the porous media. This scenario assume that the hydride has been released from its container for a short amount of time prior to any chemical reaction occurring, which allows all of the hydrogen gas to be expelled from the hydride prior to the reaction and be replaced with ambient air. Pertinent model parameters are summarized in Table 2, with results from these simulations shown in Figures 3 and summarized in Table 3. The smallest diameter hydride spheres $(0.05$ inch and $1 / 4$ inch models) never reach the lower flammability limit (LFL $=0.04$ ) for hydrogen concentration, which means no reaction event occurs. For the larger spheres $(1 / 2$ inch and higher models), the LFL and/or the auto-ignition temperature $\left(500^{\circ} \mathrm{C}\right.$ or $571^{\circ} \mathrm{C}$ depending on the $\mathrm{H}_{2}$ concentration) of hydrogen is reached and a reaction event occurs. Thus, there is a critical radius between $1 / 4$ and $1 / 2$ inch that indicates the minimum amount of material necessary for a hydrogen reaction event to occur.

Table 2: Model Parameters for porous $2 \mathrm{LiBH}_{4} \cdot \mathrm{MgH}_{2}$

\begin{tabular}{|c|c|c|c|c|}
\hline Parameter & \multicolumn{4}{|c|}{ Value } \\
\hline Material porosity $(\varepsilon)$ & \multicolumn{4}{|l|}{0.5} \\
\hline Particle Diameter $\left(D_{p}\right)$ & \multicolumn{4}{|c|}{$3.7 \times 10^{-6} \mathrm{~m}$} \\
\hline Material density $(\rho)$ & \multicolumn{4}{|c|}{$927 \mathrm{~kg} / \mathrm{m}^{3}$} \\
\hline Material thermal conductivity $(k)$ & \multicolumn{4}{|c|}{$0.5 \mathrm{~W} / \mathrm{m}-\mathrm{K}$} \\
\hline Material specific heat $\left(C_{p}\right)$ & \multicolumn{4}{|c|}{$1583 \mathrm{~J} / \mathrm{kg}-\mathrm{K}$} \\
\hline Heat/Mass generation & \multicolumn{4}{|c|}{ Based on calorimetry data } \\
\hline Reaction propagation & \multicolumn{4}{|c|}{$0.03 \mathrm{~mm} / \mathrm{s}^{*}$} \\
\hline \multirow[t]{8}{*}{ Model dimensions: } & Model & $r_{1}$ (in) & $r_{2}$ (in) & $r_{3}$ (in) \\
\hline & 0.05 in & 0.00 & 0.05 & 10.05 \\
\hline & $1 / 4$ in & 0.20 & 0.25 & 10.25 \\
\hline & $1 / 2$ in & 0.45 & 0.50 & 10.50 \\
\hline & 1 in & 0.95 & 1.00 & 11.00 \\
\hline & $1 \frac{1 / 2}{\text { in }}$ & 1.45 & 1.50 & 11.50 \\
\hline & 2 in & 1.95 & 2.00 & 12.00 \\
\hline & $21 / 2$ in & 2.45 & 2.50 & 12.50 \\
\hline
\end{tabular}

Note: *based on contamination model [8]

Figure 2 shows the species concentration major components of the hydrogen-air reaction for the $1 / 2$ inch sphere model. Note that as the $\mathrm{H}_{2}$ and $\mathrm{O}_{2}$ burn away, water vapor $\left(\mathrm{H}_{2} \mathrm{O}\right)$ increases in their place. Similar results are seen for the larger spheres (1 inch and greater models), but are not shown.

For the second scenario, the hydride is initialized with hydrogen gas filling the porous media. This scenario assume that the chemical reaction occurs immediately after the hydride is released from its container, which means the porous space within the hydride is still full of $100 \%$ hydrogen gas at the start of the numerical simulation. It was observed that due to the high dissipation rate of $\mathrm{H}_{2}$ into the ambient atmosphere, most of the hydrogen has been expelled from the hydride prior to the start of the chemical reaction (mass/heat generation) within the simulation. Thus, the hydrogen-initialized hydride models yielded similar results to the air-initialized hydride models and are not shown. 


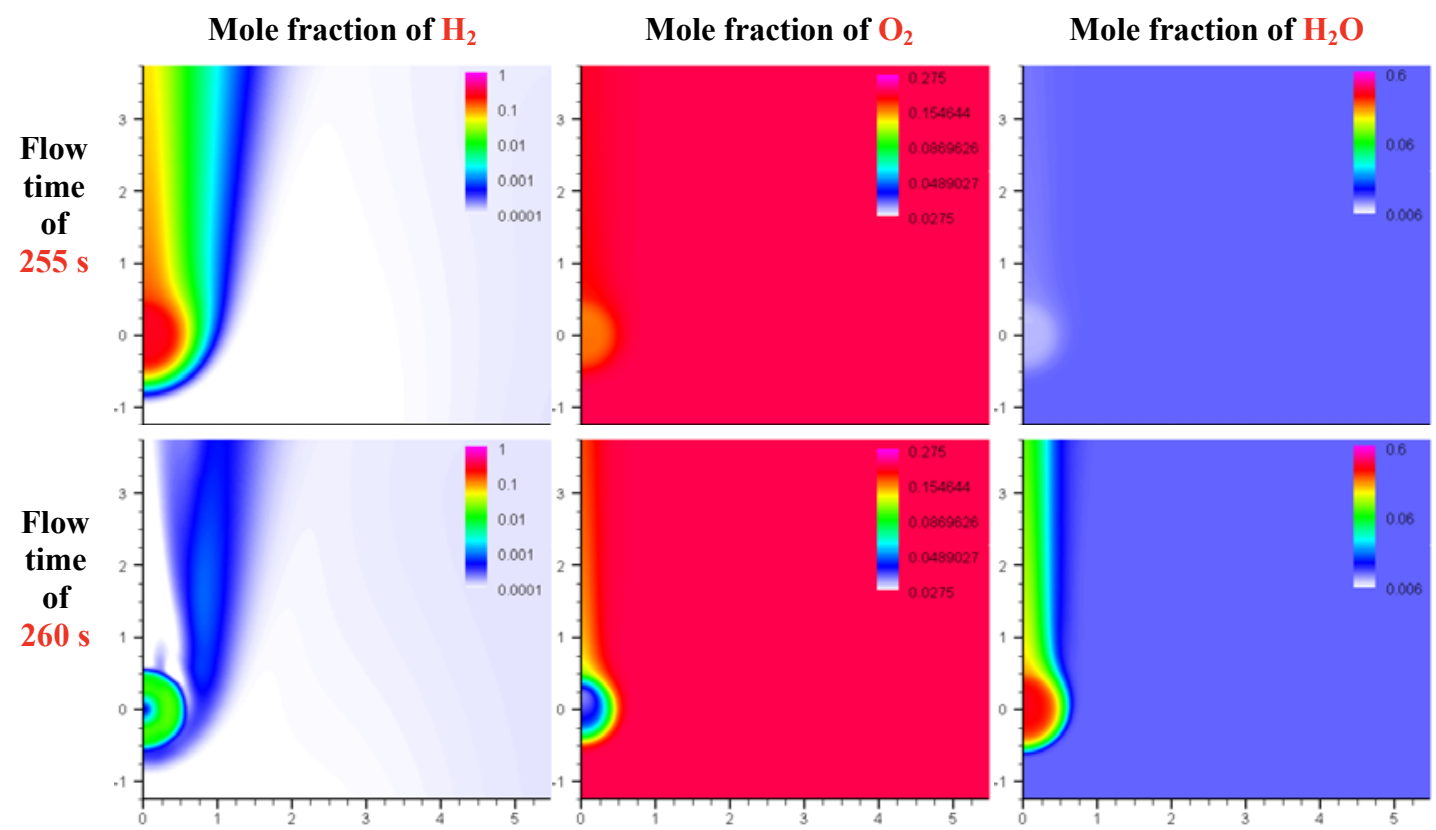

Figure 3: Mole fractions of $\mathrm{H}_{2}, \mathrm{O}_{2}$, and $\mathrm{H}_{2} \mathrm{O}$ before and after hydrogen ignition (255s and 260 s, respectively) for the axi-symmetric sphere with a $1 / 2$ inch radius.

Table 3: Axisymmetric Sphere Results for air-initialized hydride

\begin{tabular}{|c|c|c|c|}
\hline Model & $\mathrm{H}_{2}$ Ignition Event & $\mathrm{H}_{2}$ mole fraction $(\mathrm{mf})$ & Temperature \\
\hline 0.05 in & None & $\begin{array}{l}\text { Maximum value of } 0.0123 \\
\text { at } \mathrm{t}=160 \mathrm{~s}\end{array}$ & $\begin{array}{c}\text { Maximum temperature of } \\
164.2^{\circ} \mathrm{C} \text { at } \mathrm{t}=300 \mathrm{~s}\end{array}$ \\
\hline $1 / 4$ in & None & $\begin{array}{c}\text { LFL reached between } \\
t=55 \mathrm{~s} \text { and } 60 \mathrm{~s} \\
\text { Max of } 0.135 \text { at } t=230 \mathrm{~s}\end{array}$ & $\begin{array}{c}\text { Maximum temperature of } \\
752.4^{\circ} \mathrm{C} \text { at } \mathrm{t}=370 \mathrm{~s}\end{array}$ \\
\hline $1 / 2$ in & $\begin{array}{c}\text { Between } \mathrm{t}=255 \mathrm{~s} \& 260 \mathrm{~s}: \\
\mathrm{H}_{2} \mathrm{mf}=0.266 \text { and } 0.015 \\
\text { Temp }=569^{\circ} \mathrm{C} \text { and } 571^{\circ} \mathrm{C}\end{array}$ & $\begin{array}{c}\text { LFL reached between } \\
t=30 \mathrm{~s} \text { and } 35 \mathrm{~s} \\
\text { Max of } 0.266 \text { at } t=255 \mathrm{~s}\end{array}$ & $\begin{array}{c}\text { Maximum temperature of } \\
1422^{\circ} \mathrm{C} \text { at } \mathrm{t}=540 \mathrm{~s}\end{array}$ \\
\hline 1 in & $\begin{array}{l}\text { Between } \mathrm{t}=200 \mathrm{~s} \& 203 \mathrm{~s}: \\
\mathrm{H}_{2} \mathrm{mf}=0.323 \text { and } 0.0503 \\
\text { Temp }=327^{\circ} \mathrm{C} \text { and } 361^{\circ} \mathrm{C}\end{array}$ & $\begin{array}{l}\text { LFL reached at } t=25 \mathrm{~s} \\
\text { Max of } 0.323 \text { at } t=200 \mathrm{~s}\end{array}$ & $\begin{array}{l}\text { Maximum temperature of } \\
2184^{\circ} \mathrm{C} \text { at } \mathrm{t}=963 \mathrm{~s}\end{array}$ \\
\hline $1.5 \mathrm{in}$ & $\begin{array}{l}\text { Between } \mathrm{t}=180 \mathrm{~s} \& 185 \mathrm{~s} \text { : } \\
\mathrm{H}_{2} \mathrm{mf}=0.343 \text { and } 0.0939 \\
\text { Temp }=263^{\circ} \mathrm{C} \text { and } 316^{\circ} \mathrm{C}\end{array}$ & 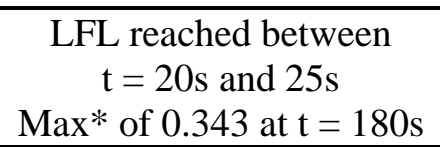 & $\begin{array}{l}\text { Temperature reaches } \\
2250^{\circ} \mathrm{C} \text { at } \mathrm{t}=1000 \mathrm{~s} \\
\text { (and still rising) }\end{array}$ \\
\hline 2 in & $\begin{array}{l}\text { Between } \mathrm{t}=170 \mathrm{~s} \& 175 \mathrm{~s} \text { : } \\
\mathrm{H}_{2} \mathrm{mf}=0.361 \text { and } 0.117 \\
\text { Temp }=234^{\circ} \mathrm{C} \text { and } 293^{\circ} \mathrm{C}\end{array}$ & $\begin{array}{c}\text { LFL reached between } \\
t=20 \mathrm{~s} \text { and } 25 \mathrm{~s} \\
\text { Max }^{*} \text { of } 0.361 \text { at } t=170 \mathrm{~s}\end{array}$ & $\begin{array}{l}\text { Temperature reaches } \\
2563^{\circ} \mathrm{C} \text { at } \mathrm{t}=1000 \mathrm{~s} \\
\text { (and still rising) }\end{array}$ \\
\hline $2.5 \mathrm{in}$ & $\begin{array}{l}\text { Between } \mathrm{t}=180 \mathrm{~s} \& 183 \mathrm{~s} \text { : } \\
\mathrm{H}_{2} \mathrm{mf}=0.410 \text { and } 0.209 \\
\text { Temp }=255^{\circ} \mathrm{C} \text { and } 668^{\circ} \mathrm{C}\end{array}$ & 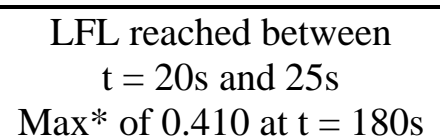 & $\begin{array}{l}\text { Temperature reaches } \\
2312^{\circ} \mathrm{C} \text { at } \mathrm{t}=1000 \mathrm{~s} \\
\text { (and still rising) }\end{array}$ \\
\hline
\end{tabular}




\section{Ammonia Borane $\left(\mathrm{NH}_{3} \mathrm{BH}_{3}\right)$}

Figure 4 shows the calorimetric behavior of ammonia borane in the charged and discharged of the as-received and dehydrogenated material for exposure to dry and humid air (30\%RH) at $40^{\circ} \mathrm{C}$ over an 18 hour period. In the case of dry air, endothermic behavior is observed with a calculated enthalpy of 5.9 and $32.1 \mathrm{~kJ} / \mathrm{mol} \mathrm{NH}_{3} \mathrm{BH}_{3}$ for the charged and discharged state respectively[9]. This behavior is attributed to ammonia borane having a low, initial dehydrogenation temperature $\left(70^{\circ} \mathrm{C}\right)$ and oxidation from exposure to air. The discharged material has a higher enthalpy value due to material stability. However, the introduction of $30 \%$ water vapor to the system initiates an exotherm of -15.2 and -49.4 $\mathrm{kJ} / \mathrm{mol} \mathrm{NH}_{3} \mathrm{BH}_{3}$ for the charged and discharged states respectively. The behavior in the discharged state is related to the decomposition of ammonia borane and the stability of the material after discharge. X-ray diffraction analysis showed pure crystalline ammonia borane starting material, Figure 5(a). However, amorphous material was identified as the resultant material after exposure to air and water vapor. This is similar to the XRD pattern of dehydrogenated material shown in Figure 5(b).

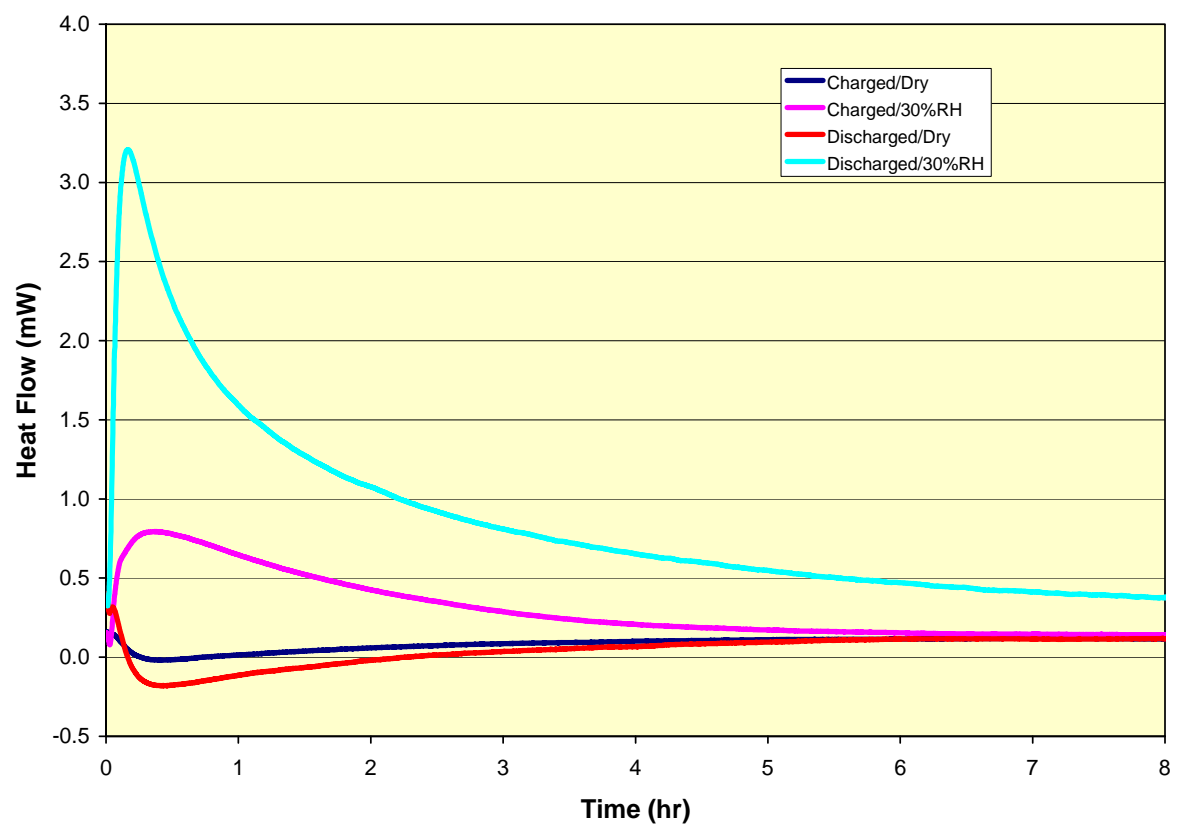

Figure 4: Heat Flow of charged and discharged Ammonia Borane for an 18 hour period in the charged and discharged state in dry air and 30\%RH environment 
(a)

(b)
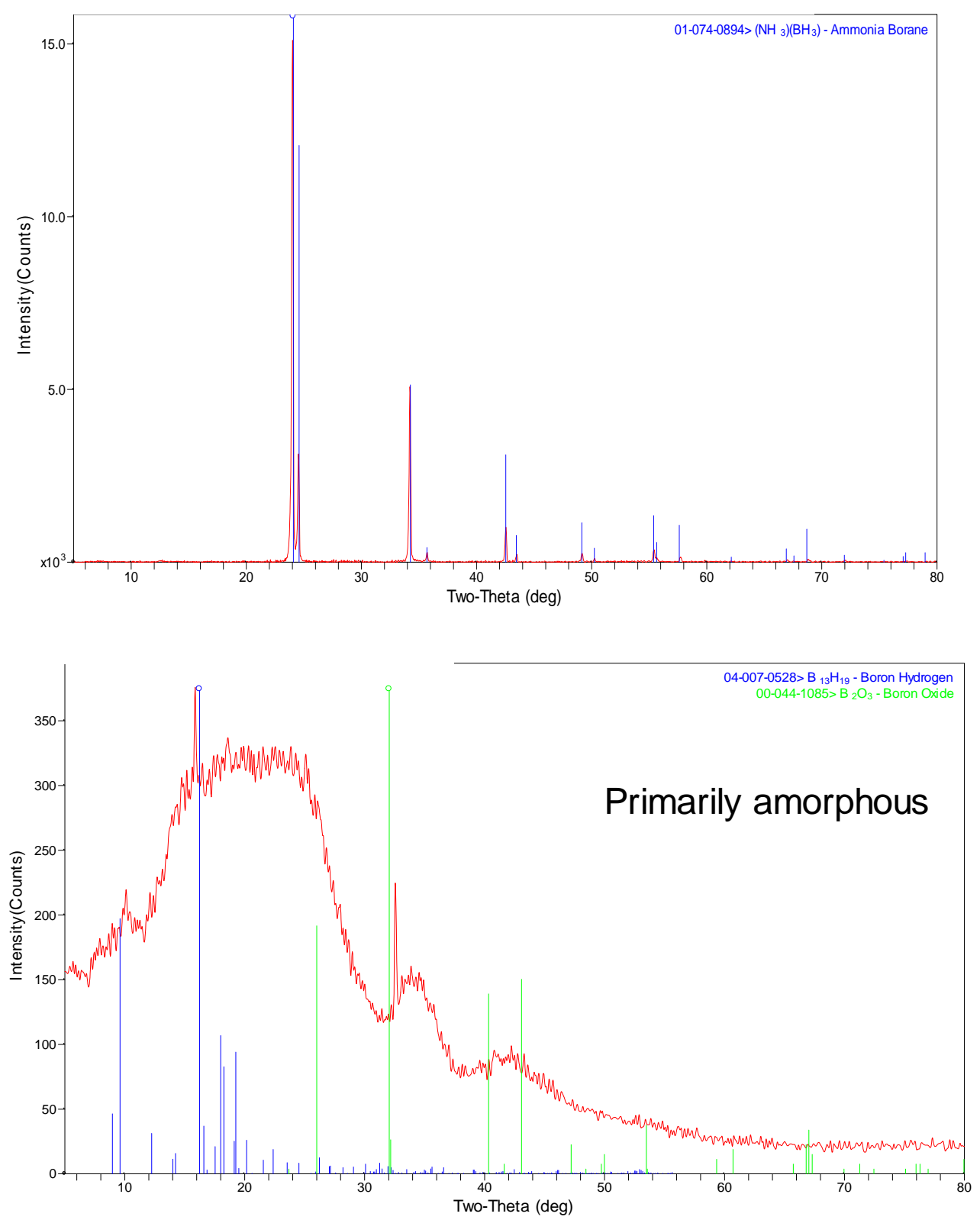

Figure 5: (a) XRD pattern of charged Ammonia Borane (b) XRD pattern of discharged Ammonia Borane 


\section{Conclusions}

As the use of solid-state hydrogen storage materials become more prevalent, the understanding of the environmental reactivity is imperative. This includes the risks and hazards associated with each material. These risks are unique for each material and thus significant experimental data needs to be generated to understand the reactivity of these materials with potential environmental scenarios. This study has shown the calorimetric results of dry and humid air exposure of both charged and discharged $2 \mathrm{LiBH} 4 \cdot \mathrm{MgH}_{2}$ and $\mathrm{NH}_{3} \mathrm{BH}_{3}$. The $2 \mathrm{LiBH}_{4} \cdot \mathrm{MgH}_{2}$ material was much more reactive than the $\mathrm{NH}_{3} \mathrm{BH}_{3}$, releasing nearly an order of magnitude more heat per mole, but still somewhat less reactive than $\mathrm{NaAlH}_{4} \cdot \mathrm{NH}_{3} \mathrm{BH}_{3}$, reacted endothermically upon exposure to both dry and humid environments with the discharged state somewhat more reactive.

A finite element modeling approach was developed to describe behavior for a breachof-tank scenario when pelletized material is ejected. This model took into account the simultaneous generation and loss of heat and hydrogen through radiative, convective means. The $2 \mathrm{LiBH}_{4} \cdot \mathrm{MgH}_{2}$ system was modeled using a 2-D axi-symmetric sphere to determine a critical radius (025 in $<\mathrm{r}<0.5$ in) for the auto-ignition of hydrogen to occur. These models incorporate thermal data from the self-heating test (UN testing) and calorimetry for water and air exposure to quantify the energy and hydrogen release rates. It was concluded that FEM approaches to predicting potential ignition events are promising. Both minimum ignition temperatures and minimum ignition concentrations were identified and potential ignition circumstances predicted. Further work in modeling and validation of the models for potential

accident scenarios is warranted in order to reduce the time and expense of performing physical experiments.

\section{Acknowledgements}

The authors would like to thank David Missimer and Joe Wheeler for their XRD and laboratory support, respectively. This work was funded under the U.S. Department of Energy (DOE) Hydrogen Storage Program managed by Dr. N. Stetson.

\section{References}

[1] Fisher M. Safety Aspects of Hydrogen Combustion in Hydrogen Energy-Systems. Int J Hydrogen Energy 1986;11:593.

[2] Fisher M. Safety Aspects in Hydrogen Energy Systems. Hydrogen Syst. Pap. Int. Symp. 1986;2:491.

[3] Hord J. How safe is hydrogen? Hydrogen Energy Distrib., Symp. Pap 1979:613.

[4] Lohstroh W, Fichtner M, Breitung W. Complex hydrides as solid storage materials: First safety tests. Int J Hydrogen Energy 2009;34:5981.

[5] Tanaka H, Tokoyoda K, Matsumoto M, Suzuki Y, Kiyobayashi T, Kuriyama N. Hazard assessment of complex hydrides as hydrogen storage materials. Int $J$ Hydrogen Energy 2009;34:3210.

[6] Vajo JJ, Skeith SL, Mertens F. Reversible Storage of Hydrogen in Destabilized LiBH4. J. Phys. Chem. B 2005;109:3719.

[7] Satyapal S, Petrovic J, Read C, Thomas G, Ordaz G. The U.S. Department of Energy's National Hydrogen Storage Project: Progress towards meeting hydrogenpowered vehicle requirements. Catalysis Today 2007;120:246.

[8] James CW, Tamburello D, Brinkman K, Gray JR, Hardy B, Anton DL. Environmental Exposure of 2LiBH4+MgH2 using Empirical and Theoretical 
Thermodynamics ICHS. Ajaccio-Corsica, France: International Journal of Hydrogen Energy, 2010.

[9] James CW, Cortes JA, Anton DL. Determination of the Environmental Reactivity within Solid-State Hydrogen Storage Systems using Theoretical Thermodynamics. 2010 In Progress.

[10] United Nations Recommendations on the Transport of Dangerous Goods, Manual of Tests and Criteria, 3rd revised edition, 1999.

[11] Brinkman KS, Gray JR, James CW, Cortes-Concepcion J, Anton DL.

Fundamental Reactivity Testing and Analysis of the Hydrogen Storage Material System 2LiBH4•MgH2. Int J Hydrogen Energy 2010:In Progress. 